Jovana Milutinović,*

UDK: 37.018 .1

Slađana Zuković,

DOI: $10.19090 /$ gff.2017.2.289-302

Senka Slijepčević

Originalni naučni rad

Filozofski fakultet

Univerzitet u Novom Sadu

\title{
MIŠLJENJE NASTAVNIKA, RODITELJA I STUDENATA PEDAGOGIJE O MODELU ŠKOLOVANJA DECE KOD KUĆE ${ }^{* *}$
}

U radu se predstavljaju iskustva i osnovne dileme školovanja u porodičnim uslovima zapadnih zemalja, mogućnosti ovog modela školovanja, kao i izvesna metodološka ograničenja $u$ istraživanjima ove problematike. Cilj rada usmeren je na sagledavanje mišljenja nastavnika, roditelja i studenata pedagogije o modelu školovanja dece kod kuće. Primenjeni instrument konstruisan je za potrebe šireg istraživanja, a uzorkom je obuhvaćen 441 ispitanik. Rezultati pokazuju da većina ispitanika ne podržava školovanje dece kod kuće, pri čemu studenti pedagogije u manjoj meri, nego nastavnici i roditelji, izražavaju negativan stav prema ovom modelu školovanja. Zaključuje se da je, u procesima demokratizacije i nastojanja da se poboljša kvalitet obrazovanja za svu decu, ključno upoznavanje učesnika obrazovnog procesa s alternativama u obrazovanju, prednostima, mogućnostima i potencijalnim nedostacima različitih modela. Takođe, neophodno je kreirati uslove za adekvatnu podršku roditeljima, kada je reč o donošenju odluke o biranju, ili pak organizovanju obrazovanja koje će odgovarati specifičnim potrebama njihove dece.

Ključne reči: alternative u obrazovanju, kvalitet obrazovanja, pedagoški pluralizam, školovanje kod kuće, školski pluralizam.

\section{UVOD}

Učestale kritike koje se upućuju školi iz mnogih segmenata društva proizašle su iz njene nemogućnosti da odgovori na zahteve savremenog društva. Uniformna organizacija škole, praćena karakteristikama sporog menjanja i inoviranja nije u mogućnosti da odgovori na raznovrsne potrebe učenika. Usled toga, unapređenje kvaliteta obrazovanja predstavlja pitanje koje je u fokusu

*jovanajm@ff.uns.ac.rs

Rad je nastao u okviru projekata Kvalitet obrazovnog sistema Srbije u evropskoj perspektivi (179010) i Pedagoški pluralizam kao osnova strategije obrazovanja (179036) koje u periodu od 2011. do 2017. godine finansira Ministarstvo prosvete, nauke i tehnološkog razvoja Republike Srbije. 
teoretičara i praktičara savremenog obrazovanja. Međutim, vrednosti na osnovu kojih se procenjuje kvalitet obrazovanja su raznovrsne; u demokratskim i pluralnim društvima nije jednostavno postići konsenzus među suprotstavljenim interesima različitih segmenata društva (Milutinović i Zuković, 2014). Sve to dovelo je do potrebe osmišljavanja filozofije obrazovanja koja bi usmeravala obrazovnu politiku na način koji ne bi bio usmeren isključivo na zadovoljavanje potreba većine, već bi odgovarao na potrebe različitih grupa. U državama s razvijenom demokratijom rešenje ovog kompleksnog problema nalazi se u ustanovljavanju alternativa $u$ obrazovanju (Milutinović, 2011), gde je roditeljima i njihovoj deci ostavljeno pravo da sami izaberu privatnu ili alternativnu školu, javnu školu s alternativnom pedagoškom koncepcijom ili mogućnost privatnog poučavanja kod kuće kako bi se bolje zadovoljile dečje jedinstvene potrebe učenja. Prateći trendove obrazovanja u zapadnim zemljama i analizom stanja u našem školstvu, na našim se prostorima poslednjih godina polemiše o mogućnostima organizovanja nastave u porodičnim uslovima. Povod ove rasprave je Zakon o osnovnom obrazovanju i vaspitanju u Srbiji iz 2013. godine (Službeni glasnik RS, Br. 55/2013, član 38) u kojem je utvrđeno da roditelj, odnosno staratelj ima pravo da organizuje svom detetu osnovnoškolsko obrazovanje i vaspitanje kod kuće. Otuda postoji potreba da se sagledaju iskustva zapadnih zemalja u organizovanju školovanja u porodičnim uslovima, kao i prednosti i ograničenja ovog vida alternativnog obrazovanja.

\section{MODEL ŠKOLOVANJA DECE KOD KUĆE KAO ALTERNATIVA U OBRAZOVANJU}

Iako školovanje dece kod kuće ima viševekovnu tradiciju, dugotrajniju od institucionalnog obrazovanja, savremeni pokret školovanja dece kod kuće razvio se sredinom 20. veka, kao jedna od liberalnih alternativa javnim školama. Razlozi zbog kojih su se roditelji odlučivali za ovu alternativu u obrazovanju jesu različiti i menjali su se tokom vremena. Za razliku od školovanja dece u krugu porodice $u$ prošlosti, gde su glavni razlozi za ovakav vid obrazovanja isključivo praktične prirode, savremeni pokret školovanja kod kuće više predstavlja čin političkog protesta protiv institucija formalnog obrazovanja $\mathrm{s}$ izraženom ideološkom podlogom (Gaither, 2009). Reč je o tome da se u Sjedinjenim Američkim Državama, od sedamdesetih godina 20. veka, počeo razvijati pokret školovanja kod kuće kao rezultat povećanja broja porodica koje su pokrenule mnoge, čak radikalne, političke i pravne postupke u cilju obezbeđivanja pravnih uslova za obrazovanje dece kod kuće (Kunzman \& Gaither, 2013). Osamdesetih godina 20. veka ovom pokretu se priključuju i roditelji koji bi se uslovno mogli svrstati u konzervativnu 
struju (Lines, 2000). Neki od njih verovali su da je njihova religijska dužnost da školuju decu kod kuće, a drugi su nastojali da integrišu religiju, učenje i porodični život (Milutinović i Zuković, 2014).

Postoje različiti motivi zbog kojih se roditelji (i konzervativne i liberalne orijentacije) danas opredeljuju da školuju svoju decu kod kuće. Pojedini roditelji koji biraju ovaj model školovanja predstavljaju deo šireg socijalnog pokreta koji predstavlja opozit neadekvatnom institucionalnom obrazovanju, dok drugi roditelji biraju ovu opciju kao alternativu institucionalnom obrazovanju bez pozivanja na njegove nedostatke (Kunzman \& Gaither, 2013). Međutim, bez obzira na filozofsku i ideološku orijentaciju roditelja, razlozi za odabir modela školovanja u krugu porodice često su slični (Dumas, Gates \& Schwarzer, 2010: 70). Prema nekim istraživanjima (Planty et. al., 2009), razlozi za školovanje dece kod kuće u Sjedinjenim Američkim Državama jesu: želja da se obezbedi adekvatno religijsko i moralno vaspitanje, zabrinutost koja je povezana s neadekvatnom klimom u školi, nezadovoljstvo $\mathrm{s}$ akademskom ponudom škole, neslaganje $\mathrm{s}$ tradicionalnim pristupom obrazovanju, specifične potrebe deteta, kao i postojanje različitih smetnji u njegovom razvoju. Iako u Sjedinjenim Američkim Državama školovanje kod kuće obuhvata mnogobrojniju populaciju nego što je to slučaj u evropskom prostoru, ovo područje istraživanja zauzima sve veću pažnju istraživača iz Evrope. Što se tiče razloga zbog kojih roditelji u Evropi biraju da školuju svoju decu kod kuće, prisutna je izvesna podudarnost s navedenim razlozima odabira ovog modela obrazovanja $u$ Sjedinjenim Američkim Državama.

Veoma različiti razlozi zbog kojih se roditelji opredeljuju da školuju decu kod kuće impliciraju i veliku raznosvrsnost u ciljevima obrazovanja koji se postavljaju u porodičnim uslovima, kao i u načinima njihovog postizanja. Razlike među roditeljima koji se opredeljuju da decu školuju kod kuće mogu se predstaviti i dihotomijom koju je Džejn Van Galen (Jane Van Galen) istakla još 1988. godine (prema: Kunzman \& Gaither, 2013: 13), a odnosi se na dve široke grupe praktičara školovanja kod kuće - „ideolozi” i „,pedagozi”. „Ideologe” pretežno predstavljaju roditelji konzervativne hrišćanske orijentacije koji biraju visoko strukturisano okruženje učenja sa striktnim rasporedom i formalnim kurikulumom u okviru kojeg se upotrebljavaju tradicionalne metode poučavanja. „Pedagozi” su roditelji koji kritikuju formalizam javnih škola; oni u organizovanju obrazovanja kod kuće biraju manje strukturisan pristup, ili se čak zalažu za potpunu slobodu u učenju. Značajno je i to da roditelji koji školuju decu kod kuće koriste i različite materijale za učenje; neki roditelji biraju komercijalne materijale koji se primenjuju u redovnim školama, dok ih drugi sami osmišljavaju. U Sjedinjenim Američkim Državama postoji praksa kreiranja kooperativnih centara, sportskih timova, klubova, pa čak i društvenih 
centara u kojima se učenje organizuje na način koji je sličan nastavnom radu u tradicionalnim školama. Osim toga, poslednjih nekoliko godina omogućava se da deca koja se školuju kod kuće dobiju kompletno javno obrazovanje putem virtuelnih učionica (Gaither, 2009). Takođe, širom sveta danas deluju raznovrsne obrazovne ustanove i asocijacije koje nude stručnu pomoć i pomažu roditeljima da organizuju obrazovanje kod kuće. Roditeljima i njihovoj deci nude se raznovrsni didaktički paketi, knjige i drugi obrazovni materijali, pri čemu im na raspolaganju stoje mnoge biblioteke, muzeji, bolnice, crkve, fabrike i dodatni kursevi (Lines, 2000).

\section{Istraživanja o akademskim prednostima modela školovanja kod kuće}

Pregled literature o obrazovanju dece kod kuće ukazuje na rastući konsenzus o akademskim prednostima ovakvog modela školovanja. Rezultati mnogih istraživanja o akademskim postignućima dece koja se školuju kod kuće (Blok, 2004; Dumas, Gates \& Schwarzer, 2010; Hagen, 2011; Lines, 2000), pokazuju da ovi učenici postižu prosečne, a često i rezultate koji su iznad proseka. Pojedina istraživanja (Frost \& Morris, 1988), pokazuju da deca školovana kod kuće postižu iznadprosečne rezultate na testovima iz svih predmeta, osim matematike, a pretpostavlja se da je razlog tome dominantna zastupljenost metode razgovora $u$ obrazovanju u porodičnim uslovima. Ovo u nekoj meri objašnjava i zbog čega deca školovana kod kuće pokazuju izvanredne verbalne kompetencije. Ispitivanja takođe pokazuju da su deca koja se školuju kod kuće socijalno zrelija u odnosu na vršnjake koji pohađaju školu (Dumas, Gates \& Schwarzer, 2010; Petrie, 2001; Medlin, 2000). Međutim, prilikom tumačenja rezultata ispitivanja efekata školovanja dece kod kuće potrebno je imati u vidu ograničenja tih istraživanja.

U literaturi se (Kunzman \& Gaither, 2013) ističe da osnovno ograničenje istraživanja školovanja kod kuće čini nedostupnost subjekata istraživanja i tačnih demografskih podataka, što je jedan od razloga zašto su istraživanja pretežno kvalitativna. Iako ta istraživanja pružaju dublji uvid u razumevanje fenomena, ona ipak nisu podložna generalizaciji. Takođe, procena nekih autora jeste (Blok, 2004) da populaciju dece koja se školuju kod kuće čine već privilegovana deca čiji roditelji imaju viši stepen obrazovanja, više resursa i kompetencija za organizovanje školovanja kod kuće. Uz to, oni imaju i visoka očekivanja i motivaciju kada je u pitanju akademsko postignuće i razvoj vlastite dece. Sveobuhvatno istraživanje akademskog postignuća dece koja su školovana kod kuće u Sjedinjenim Američkim Državama, sa preko 20,000 ispitanika, pokazuje da ta deca postižu izuzetno visoke rezultate na standardizovanim testovima, čak znatno više od populacije učenika koji 
se školuju u javnim ili privatnim školama (Rudner, 1999). Međutim, iako je uzorak ispitanika veoma veliki, posebno za tako specifičnu grupu, demografske karakteristike ispitanika ne reflektuju generalnu populaciju, već pripadaju privilegovanom sloju stanovništva. Shodno tome, poređenje akademskih postignuća ispitanika s ukupnom populacijom učenika u javnom i privatnom sektoru školstva predstavlja jedan od ključnih metodoloških nedostataka te studije. U tom okviru, pojedina istraživanja o akademskim postignućima (Martin-Chang, Gould \& Meuse, 2011) sprovedena su upravo na način koji bi omogućio da se, prema sociodemografskim varijablama, ujednače deca koja su školovana kod kuće i deca uključena u institucionalno obrazovanje. Međutim, pokazalo se da je uzorak istraživanja suviše mali da bi rezultati mogli da se generalizuju. Sprovedenim istraživanjem potvrđeno je da u akademskom smislu postoje prednosti školovanja kod kuće. Međutim, istraživanjem su, kada je reč o postignućima na standardizovanim testovima, utvrđene i razlike između roditelja koji školuju decu prema visokostrukturisanom kurikulumu i roditelja koji preferiraju potpunu slobodu u učenju. Može se zaključiti da većina istraživanja pokazuje određene prednosti školovanja kod kuće. S druge strane, metodološka ograničenja spomenutih istraživanja, posebno kada je reč o sociodemografskim karakteristikama ispitanika, onemogućuju izvođenje generalizovanih zaključaka o tome da li su visoki rezultati dece školovane kod kuće posledica ovakvog pristupa obrazovanju ili bolje početne pozicije ove dece.

\section{Zastupljenost školovanja kod kuće u evropskom kontekstu}

Posmatrano u širem evropskom kontekstu, školovanje kod kuće danas je u većem broju zemalja legalno priznato i zakonski regulisano. Autori iz zemalja zapadne Evrope (Merry \& Karsten, 2010; Spiegler, 2009; Villalba, 2009) pretežno zastupaju stanovište da je neophodna pravna regulacija modela školovanja dece kod kuće s obzirom na to da zakoni predviđaju da deca osnovnoškolskog uzrasta moraju redovno pohađati neku obrazovno-vaspitnu instituciju (državnu ili privatnu). U tom smislu, neke zemlje poput Španije, Grčke, Švajcarske (pojedini kantoni), Holandije, Nemačke i Bugarske ne omogućavaju školovanje kod kuće, osim u posebnim okolnostima. U ostalim evropskim zemljama, uključujući Belgiju, Dansku, Estoniju, Finsku, Francusku, Irsku, Italiju, Norvešku, Portugaliju, Švedsku, Švajcarsku (pojedini kantoni), Englesku i Austriju, školovanje dece kod kuće je zakonski omogućeno, praćeno umerenom ili visokom regulacijom i kontrolom od strane države (Blok \& Karsten, 2011; Petrie, 2001). Ipak, evidentno je da interesovanje za model školovanja dece kod kuće, kao alternative formalnom 
školovanju, predstavlja još uvek marginalni fenomen i da nju uglavnom biraju roditelji čija su deca bolesna, sa smetnjama u razvoju ili darovita (Sliwka \& Istance, 2006).

Iako u većini postkomunističkih zemalja model školovanja dece kod kuće predstavlja relativno novi fenomen, u novije vreme primetan je kontinuirani porast interesovanja za njega (Kostelecká, 2010; Sliwka \& Istance, 2006). Mogućnost za roditelje da školuju decu kod kuće uvođena je različitim tempom kao legalna opcija obrazovanja, najpre u Poljskoj, a potom u Rusiji, Estoniji, Mađarskoj, Republici Sloveniji, Češkoj Republici i Slovačkoj Republici. Iako u ovim zemljama postoje različita rešenja po pitanju zakonske regulative kojom se uređuje mogućnost ostvarivanja prava školovanja dece kod kuće, postoje i mnoge zajedničke odlike. Komparativna istraživanja pokazala su da je, na primer, u Poljskoj, Estoniji, Slovačkoj Republici, Republici Sloveniji i Mađarskoj, zakonom predviđeno da škola kao institucija ima ulogu nadgledanja obrazovanja koje roditelji realizuju sa decom kod kuće (Kostelecká, 2010).

Polazeći od iznetih postavki o tome da je školovanje dece kod kuće legalno priznato i zakonski regulisano u većem broju evropskih zemalja, predmet ovog rada odnosi se na razmatranje pretpostavki razvoja ovog modela školovanja u Srbiji. Stoga će u daljem tekstu biti predstavljeni rezultati kratkog empirijskog istraživanja koje se odnosilo na ispitivanje mišljenja nastavnika, roditelja i budućih stručnih saradnika - pedagoga o ovom modelu školovanja.

\section{METOD}

\section{Cilj i zadaci istraživanja.}

Cilj istraživanja usmeren je na ispitivanje mišljenja nastavnika, roditelja i studenata pedagogije o modelu školovanja dece kod kuće. U skladu s tim postavljeni su sledeći istraživački zadaci: 1. ispitati da li nastavnici podržavaju mogućnost školovanja dece kod kuće i da li postoje razlike u odgovorima nastavnika zavisno od godina radnog staža i tipa nastave; 2 . ispitati da li roditelji podržavaju mogućnost školovanja dece kod kuće i da li postoje razlike u odgovorima roditelja zavisno od nivoa obrazovanja i procenjenog materijalnog stanja porodice; 3 . ispitati da li studenti pedagogije podržavaju mogućnost školovanja dece kod kuće i da li postoje razlike u odgovorima studenata pedagogije zavisno od godine studija i 4 . ispitati da li postoje razlike u odgovorima nastavnika, roditelja i studenata pedagogije o mogućnosti školovanja dece kod kuće. 
Instrument istraživanja i uzorak.

Za potrebe šireg istraživanja o razvoju školskog i pedagoškog pluralizma u Republici Srbiji (opširnije u: Zuković i Milutinović, 2013) konstruisan je instrument čiji je sastavni deo činilo i pitanje o mišljenjima ispitanika o modelu školovanja dece kod kuće. Pored opcije ponuđenih odgovora, data je i opcija odgovora otvorenog tipa $\mathrm{u}$ okviru koje su ispitanici imali mogućnost da iznesu svoje argumente za odabrani odgovor. Takođe, instrumentom su prikupljeni i podaci o sociodemografskim karakteristikama ispitanika.

Uzorak istraživanja čini 441 ispitanik, i to: nastavnici razredne i predmetne nastave $(\mathrm{N}=153)$, roditelji čija deca pohađaju osnovnu školu $(\mathrm{N}=189)$ i studenti pedagogije sa Filozofskog fakulteta Univerziteta u Novom Sadu $(\mathrm{N}=99)$. Većina ispitanih nastavnika $(49,7 \%)$ ima više od 15 godina radnog staža, 34,6\% nastavnika ima od 5 do 15 godina radnog staža, dok $15,7 \%$ ispitanih nastavnika ima manje od 5 godina radnog staža. Što se tiče tipa nastave, distribucija ispitanih nastavnika je ujednačenija (45,8\% nastavnika razredne nastave i 54,2\% nastavnika predmetne nastave). Sociodemografske karakteristike roditelja ukazuju da najveću grupu čine roditelji s višom i visokom školom $(52,4 \%)$, potom roditelji sa srednjoškolskim nivoom obrazovanja $(38,1 \%)$, dok najmanju grupu čine roditelji s magistraturom i doktoratom $(5,3 \%)$ i roditelji s osnovnoškolskim nivoom obrazovanja $(4,2 \%)$. Većina roditelja je materijalno stanje svoje porodice procenila kao srednje $(67,2 \%)$, dok je manji broj roditelja procenio materijalno stanje kao dobro (28\%) i kao loše $(4,8 \%)$. Ispitani su studenti sa 2 . godine $(54,5 \%)$ i sa 4 . godine $(45,4 \%)$ osnovnih akademskih studija pedagogije.

Tok istraživanja i statistička obrada.

Istraživanje je obavljeno u osnovnim školama sa teritorije grada Novog Sada i na Odseku za pedagogiju, Filozofskog fakulteta Univerziteta u Novom Sadu. Za statističku obradu podataka primenjen je softverski paket SPSS 12.0. U okviru deskriptivne statistike merene su prosečne vrednosti (aritmetička sredina) i mere disperzije rezultata (standardna devijacija), a u cilju analize statističke značajnosti razlika primenjen je $\chi^{2}$ test.

\section{REZULTATI ISTRAŽIVANJA}

$\mathrm{Na}$ osnovu dobijenih odgovora utvrđeno je da prosečan skor na nivou ukupnog uzorka iznosi $\mathrm{M}=1,6$, uz $\mathrm{SD}=0,8$, što znači da većina ispitanih nastavnika, 
roditelji i studenta pedagogije nema pozitivan stav prema modelu školovanja dece kod kuće. Odgovori dobijeni na nivou pojedinačnih grupa ispitanika prikazani su u Tabeli 1.

Tabela 1. Odgovori ispitanika na pitanje o podržavanju mogućnosti školovanja kod kuće

\begin{tabular}{|c|c|c|c|c|c|c|c|c|c|c|}
\hline & \multicolumn{8}{|c|}{ Da li podržavate mogućnost školovanja dece kod kuće? } & & \\
\hline & \multicolumn{2}{|c|}{$\mathrm{Ne}$} & \multicolumn{2}{|c|}{$\begin{array}{l}\text { Neodlučan } \\
\text { sam }\end{array}$} & \multicolumn{2}{|c|}{$\mathrm{Da}$} & \multicolumn{2}{|c|}{ nedostajući } & & \\
\hline & $f$ & $\%$ & $f$ & $\%$ & $f$ & $\%$ & $f$ & $\%$ & $A S$ & $S D$ \\
\hline Nastavnici & 81 & 52,9 & 34 & 22,2 & 37 & 24,2 & 1 & 0,7 & 1,7 & 0,8 \\
\hline Roditelji & 120 & 63,5 & 32 & 16,9 & 33 & 17,5 & 4 & 2,1 & 1,5 & 0,8 \\
\hline $\begin{array}{l}\text { Studenti } \\
\text { pedagogije }\end{array}$ & 47 & 47,5 & 35 & 35,4 & 17 & 17,2 & 0 & 0 & 1,7 & 0,7 \\
\hline
\end{tabular}

Odgovori nastavnika. Rezultati dobijeni na nivou uzorka nastavnika razredne i predmetne nastave pokazuju da većina ispitanih nastavnika $(52,9 \%)$ ne podržava mogućnost školovanja dece kod kuće. Neodlučnost po ovom pitanju pokazalo je oko $20 \%$ nastavnika, dok je podržavajući odnos prema ovom vidu školovanja pokazalo oko $24 \%$ ispitanika.

Analizom $\chi^{2}$ testa utvrđeno je da nema statistički značajnih razlika $u$ odgovorima nastavnika s obzirom na dužinu radnog staža $\left(\chi^{2}(4)=2,43, p=.66\right)$. Međutim, statistički značajne razlike u odgovorima nastavnika utvrđene su kod varijable koja se odnosi na tip nastave $\left(\chi^{2}(2)=7,38, \mathrm{p}<.05\right)$, i to kod opcija neodlučnog i podržavajućeg stava. Veći procenat nastavnika razredne nastave izrazio je neodlučan stav, dok je veći procenat nastavnika koji predaju predmetnu nastavu istakao podržavajući odnos prema ovom vidu školovanja (Tabela 2).

Tabela 2. Odgovori nastavnika s obzirom na tip nastave

\begin{tabular}{|l|l|c|c|c|c|}
\hline \multicolumn{2}{|l|}{ Tip nastave } & \multicolumn{3}{|c|}{ Da li podržavate mogućnost školovanja dece kod } & \multirow{2}{*}{ Ukupno } \\
\cline { 3 - 5 } & & $\mathrm{Ne}$ & Neodlučan sam & Da & \\
\multirow{4}{*}{ Razredna } & $f$ & 39 & 19 & 10 & 68 \\
\cline { 2 - 6 } & $\%$ & $57,4 \%$ & $27,9 \%$ & $14,7 \%$ & $100,0 \%$ \\
\multirow{3}{*}{ Predmetna } & $f$ & 41 & 14 & 27 & 82 \\
\cline { 2 - 6 } & $\%$ & $50,0 \%$ & $17,1 \%$ & $32,9 \%$ & $100,0 \%$ \\
\hline \multirow{2}{*}{ Ukupno } & $f$ & 80 & 33 & 37 & 150 \\
\cline { 2 - 6 } & $\%$ & $53,3 \%$ & $22,0 \%$ & $24,7 \%$ & $100,0 \%$ \\
\hline
\end{tabular}


Odgovori roditelja. Rezultati dobijeni na nivou uzorka roditelja pokazuju da najveći procenat roditelja $(63,5 \%)$ nema podržavajući stav prema školovanju dece kod kuće. S druge strane, podržavajući odnos prema ovakvoj vrsti školovanja pokazuje oko $17 \%$ roditelja, a približno isti procenat roditelja $(16,9 \%)$ neodlučan je po ovom pitanju.

Analizom $\chi^{2}$ testa utvrđeno je da materijalno stanje porodice nije faktor koji determiniše stav roditelja prema školovanju dece kod kuće. $\left(\chi^{2}(2)=0,11, p=.95\right)$. S druge strane, utvrđeno je postojanje statistički značajnih razlika u odgovorima roditelja s obzirom na nivo njihovog obrazovanja $\left(\chi^{2}(2)=7,26, p<.05\right)$, jer roditelji s nižim nivoima obrazovanja imaju negativniji stav po ovom pitanju, $u$ odnosu na roditelje s višim nivoima obrazovanja (Tabela 3 ).

Tabela 3. Odgovori roditelja s obzirom na nivo obrazovanja

\begin{tabular}{|c|c|c|c|c|c|}
\hline \multirow{2}{*}{\multicolumn{2}{|c|}{ Nivo obrazovanja roditelja }} & \multicolumn{3}{|c|}{$\begin{array}{l}\text { Da li podržavate mogućnost školovanja } \\
\text { dece kod kuće? }\end{array}$} & \multirow[t]{2}{*}{ Ukupno } \\
\hline & & $\mathrm{Ne}$ & Neodlučan sam & $\mathrm{Da}$ & \\
\hline \multirow[t]{2}{*}{ Osnovna i srednja škola } & $F$ & 58 & 11 & 8 & 77 \\
\hline & $\%$ & $75,3 \%$ & $14,3 \%$ & $10,4 \%$ & $100,0 \%$ \\
\hline \multirow{2}{*}{$\begin{array}{l}\text { Viša/visoka škola, } \\
\text { magistratura ili doktorat }\end{array}$} & $F$ & 61 & 21 & 25 & 107 \\
\hline & $\%$ & $57,0 \%$ & $19,6 \%$ & $23,4 \%$ & $100,0 \%$ \\
\hline \multirow[t]{2}{*}{ Ukupno } & $F$ & 119 & 32 & 33 & 184 \\
\hline & $\%$ & $64,7 \%$ & $17,4 \%$ & $17,9 \%$ & $100,0 \%$ \\
\hline
\end{tabular}

Odgovori studenata pedagogije. Na nivou uzorka studenata pedagogije dobijena je nešto drugačija slika nego kod prethodne dve grupe ispitanika. Naime, iako i većina ispitanih studenta ne podržava školovanje dece kod kuće $(47,5 \%)$, značajan broj studenata nema jasno izražen ni pozitivan ni negativan stav po ovom pitanju (35,4\%), dok je potpuno podržavajući odnos prema ovakvom obliku školovanja izrazilo $17,2 \%$ studenata pedagogije.

Analizom $\chi^{2}$ testa nije utvrđena statistički značajna razlika u stavovima studenata pedagogije prema školovanju dece kod kuće, zavisno od godine studija $\left(\chi^{2}(2)=0,30, p=.99\right)$. To znači da studenti II i IV godine studija imaju slično mišljenje po ovom pitanju.

Razlike u odgovorima roditelja, nastavnika $i$ studenata pedagogije. Dobijeni rezultati pokazali su da postoji statistički značajna razlika između odgovora nastavnika, roditelja i studenata pedagogije $\left(\chi^{2}(4)=15,36, p<.001\right)$. Dobijena razlika ogleda se u tome da su studenti pedagogije u manjoj meri, nego nastavnici i roditelji, izrazili negativno mišljenje o ovom pitanju. Tačnije rečeno, studenti pedagogije su u većoj meri, u odnosu na druge dve grupe ispitanika, 
iskazali neodlučnost ili potpuno podržavajući odnos prema ovakvom obliku školovanja.

\section{DISKUSIJA I ZAKLJUČAK}

Iako je prikazano istraživanje sprovedeno na prigodnom uzorku koji otežava mogućnost generalizacije dobijenih rezultata, na osnovu iznetih podataka evidentan je nedovoljno podržavajući odnos prema školovanju dece kod kuće. Kvalitativna analiza pitanja otvorenog tipa pokazala je da najučestaliji razlog zbog kojeg ispitanici ne podržavaju mogućnost školovanja dece kod kuće predstavlja uverenje da ovakvo obrazovanja ,isključuje” dete iz života škole, što u značajnoj meri utiče na njegovu socijalizaciju. Osim toga, i nastavnici i roditelji u velikoj meri izražavaju sumnju u mogućnost da se obrazovanjem dece kod kuće ostvari zadovoljavajući nivo kvaliteta obrazovanja. Slični razlozi mogu se uočiti i u nekim odgovorima studenata koji su izrazili bojazan da opcija obrazovanja dece kod kuće može otvoriti prostor za zloupotrebe na štetu dece. S druge starne, značajan broj studenata ima jasno izražen stav da školovanje dece kod kuće unapređuje kvalitet obrazovanja, ali uz istovremeno iskazanu sumnju da ova opcija obrazovanja adekvatno podržava socijalizaciju deteta. Ukratko rečeno, kvalitet obrazovanja i pitanje socijalizacije dece pokazali su se kao ključni argument usmereni protiv ovakvog modela obrazovanju kod ispitanika u ovoj studiji, iako su pojedina istraživanja (Blok, 2004; Martin-Chang, Gould \& Meuse, 2011; Rudner, 1999) pokazala da postignuća dece školovane kod kuće često nadmašuju rezultate dece uključene u javno školstvo.

Nalaz da studenti pedagogije (koji tokom studija dobijaju znanja vezana za alternative $u$ obrazovanju) imaju nešto manje izraženo negativno mišljenje o školovanju kod kuće, implikuje zaključak da viša pedagoška kultura i poznavanje alternativa u oblasti obrazovanja može dovesti do veće otvorenosti kada je u pitanju ovaj model školovanja. Drugim rečima, poznavanje mogućnosti školovanja kod kuće, različitih pristupa i načina organizovanja ovakvog modela obrazovanja može doprineti pozitivnijem odnosu prema ovoj obrazovnoj alternativi. S tim u vezi, otvara se pitanje da li bi upoznavanje s primerima dobre prakse školovanja kod kuće iz drugih zemalja, kao i obezbeđivanje adekvatne podrške od strane države, prikladnih materijala i kurikuluma za ovaj model obrazovanja, doprinelo pozitivnijem mišljenju o ovom pitanju u našoj široj a i užoj javnosti.

Očigledno je da ovaj model školovanja otvara i mnoga druga pitanja: da li školovanje dece kod kuće daje primat privatnim interesima u odnosu na širi javni interes u obrazovanju? Da li školovanje kod kuće otvara prostor za zloupotrebe ili 
indoktrinaciju na štetu dece? Može li dete svoje roditelje doživljavati kao istinske nastavnike? U krajnjoj liniji otvara se pitanje: da li specifične socijalne i ekonomske prilike u kojima se nalazi naša zemlja kreiraju adekvatne uslove za odabir ovog modela školovanja? (Milutinović i Zuković, 2014). S druge strane, u literaturi (Armstrong, 2008; Gardner, 2005) se ističe da postoje mnogi legitimni načina učenja, kao i mnogobrojni ispravni puteva obrazovanja. Rasprostranjeno je uverenje prema kojem mogućnost izbora u oblasti obrazovanja predstavlja značajno sredstvo poboljšanja kvaliteta obrazovanja (Boyd, 2005). Što je još važnije, temeljno ljudsko pravo za roditelja jeste da ima prvenstveno pravo da bira vrstu obrazovanja za svoju decu (UN Office of the High Commissioner for Human Rights - OHCHR, 2000). Konačno, ne treba odbacivati novine koje u oblasti obrazovanja mogu da omoguće dobit, a koje su u skladu sa temeljnim ljudskim pravima. Potrebno je samo razviti sistemsku podršku i adekvatno regulisati sistem kontrole kako bi mogućnost za roditelje da svojoj deci obezbede obrazovanje pod drugačijim okolnostima doprinela opštoj dobrobiti dece.

Jovana Milutinović, Slađana Zuković, Senka Slijepčević

OPINION OF TEACHERS, PARENTS AND PEDAGOGY STUDENTS ON THE HOMESCHOOLING

\section{Summary}

Following educational trends in the Western countries and the analysis of the situation in our education, in recent years the subject of debates in our area have been the possibilities of organizing education in family conditions. Considering that the education of children at home is legally regulated in a number of European countries, and that in the United States it has a decades-long tradition, the subject of this paper is to consider the assumptions of development of this educational model in Serbia. For this purpose, a brief empirical research was conducted related to the examination of opinions of teachers, parents and future expert associates - pedagogues on the model of homeschooling of children. The applied instrument was designed for the needs of wider research, with a sample of 441 subjects. The results show that the majority of respondents do not support homeschooling, where the students of pedagogy expressed a negative attitude towards this model of education to a lesser extent than teachers and parents. Finding that the students of pedagogy, who receive knowledge related to the alternatives in education during their studies, have a somewhat more positive opinion about homeschooling, implies that higher pedagogical culture and knowledge of alternatives in the field of education can lead to greater openness when it comes to this model of education. According to this, the question arises as to whether learning about examples of good homeschooling education from other countries, as well as providing adequate state support, appropriate materials and curricula for this model of education, will contribute to wider acceptance of this model of education in our society. In any case, it is not desirable to reject novelties that are in line with fundamental human rights and can 
provide benefits in the field of education. It is only necessary to develop systematic support and adequately administer the control system which will allow parents to provide education under different circumstances that will contribute to the general welfare of children.

Key words: alternatives in education, quality of education, pedagogical pluralism, homeschooling, school pluralism.

\section{LITERATURA}

Armstrong, T. (2008). Najbolje škole: Kako istraživanje razvoja čovjeka može usmjeravati pedagošku praksu. Zagreb: Educa.

Blok, H. (2004). Performance in Home Schooling: An Argument against Compulsory Schooling in the Netherlands. International Review of Education, 50(1), 39-52.

Blok, H., \& Karsten, S. (2011). Inspection of Home Education in European Countries. European Journal of Education, 46(1), 138-152.

Boyd, W. (2005). Markets, Choices and Educational Change. In A. Hargreaves (Ed.), Extending Educational Change: International Handbook of Educational Change. The Netherlands: Springer. 69-94.

Dumas, T. K., Gates, S., \& Schwarzer, D. R. (2010). Evidence for Homeschooling: Constitutional Analysis in Light of Social Science Research. Widener Law Review, 16(1), 63-87.

Frost, E. A., \& Morris, R. C. (1988). Does Home-Schooling Work? Some Insights for Academic Success. Contemporary Education, 59, 223-227.

Gaither, M. (2009). Homeschooling in the USA: Past, Present and Future. Theory and Research in Education, 7(3), 331-346.

Gardner, H. (2005). Disciplinarni um: obrazovanje kakvo zaslužuje svako dijete, s onu stranu činjenica $i$ standardiziranih testova. Zagreb: Educa.

Hagen, T. (2011). Free to Learn: The Rationale for Legalizing Homeschooling in Albania. Central European Journal of Public Policy, 5(2), 50-84.

Kostelecká, Y. (2010). Home Education in the Post-Communist Countries: Case Study of the Czech Republic. International Electronic Journal of Elementary Education, 3(1), 29-44. Preuzeto 7. oktobra 2013, sa http://www.iejee.com/3_1_2010/29_44.pdf

Kunzman, R., \& Gaither, M. (2013). Homeschooling: A Comprehensive Survey of the Research. Other Education: The Journal of Educational Alternatives. 2(1), 4-59.

Lines, P. M. (2000). Homeschooling Comes of Age. Public Interest, 140, 74-85. 
Martin-Chang, S., Gould, O.N., \& Meuse, R.E. (2011). The Impact of Schooling on Academic Achievement: Evidence From Homeschooled and Traditionally Schooled Students. Canadian Journal of Behavioural Science, 43(3), 195202.

Medlin, R. G. (2000). Home Schooling and the Question of Socialization. Peabody Journal of Education, 75(1-2), 107-123.

Merry, M. S., \& Karsten, S. (2010). Restricted Liberty, Parental Choice and Homeschooling. Journal of Philosophy of Education, 44(4), 497-515.

Milutinović, J. (2011). Alternative u teoriji i praksi savremenog obrazovanja: put ka kvalitetnom obrazovanju. Novi Sad: Savez pedagoških društava Vojvodine; Vršac: Visoka škola strukovnih studija za obrazovanje vaspitača „Mihailo Palov”.

Milutinović, J., \& Zuković, S. (2014). Kvalitetno obrazovanje darovitih u kontekstu modela školovanja dece kod kuće. U G. Gojkov \& A. Stojanović (ured.), Daroviti i kvalitet obrazovanja: Zbornik 19. Vršac: Visoka škola strukovnih studija za obrazovanje vaspitača „Mihailo Palov”- Vršac; Arad: Universitatea de Vest „Aurel Vlaicu”. 347-353.

Petrie, A. (2001). Home Education in Europe and the Implementation of Changes to the Law. International Review of Education, 47(5), 477-500.

Planty, M., Hussar, W., Snyder, T., Kena, G., Kewal Ramani, A., Kemp, J., Bianco, K., \& Dinkes, R. (2009). The Condition of Education 2009. Washington DC: Government Printing Office.

Rudner, L. M. (1999). Scholastic Achievement and Demographic Characteristics of Home School Students in 1998. Education Policy Analysis Archives, 7(8). doi: http://dx.doi.org/10.14507/epaa.v7n8.1999

Sliwka, A., \& Istance, D. (2006). Choice, Diversity and „Exit” in Schooling - A Mixed Picture. European Journal of Education, 41(1), 45-58.

Spiegler, T. (2009). Why State Sanctions Fail to Deter Home Education. An Analysis of Home Education in Germany and its Implications for Home Education Policies. Theory and Research in Education, 7(3), 297-309.

UN Office of the High Commissioner for Human Rights - OHCHR (2000). Human Rights: A Basic Handbook for UN Staff. 2000. Preuzeto 25. oktobra 2013, sa http://www.refworld.org/docid/483eac7b2.html

Villalba, C. M (2009). Home-Based Education in Sweden: Local Variations in Forms of Regulation. Theory and Research in Education, 7(3), 277-296.

Zakon o osnovnom obrazovanju $i$ vaspitanju (2013). Službeni glasnik RS. Br. 55/2013. 
Zuković, S., \& Milutinović, J. (2013). Razvoj školskog i pedagoškog pluralizma u Republici Srbiji; u Radovan Grandić (ur.), Obrazovni sistem i vrednosti iz ugla pluralizma $i$ autonomije ličnosti. Novi Sad: Pedagoško društvo Vojvodine. 79-96. 